\title{
Trainees' Perceptions on Project-Based Learning in Computer Graphic Design Training
}

\author{
Muhammad Kholil, Sutarto Hadiprayitno
}

\begin{abstract}
The Project-Based Learning Model (PjBL) is one of the models used in vocational learning because it provides learning experiences to produce a product. The purpose of this paper is to describe the trainee's responses to the benefits gained from the experience of the PjBL activities in the Computer Graphic Design training, which are based on four aspects, technical skill development, project management, teamwork, and relevance. The study was conducted among 31 trainees at the Vocational Training Center in Sleman Regency. Its data collection technique uses a Likert scale questionnaire, and its data analysis technique uses descriptive statistics. The findings of the study indicated that the trainees assume that PjBL activities in computer graphic design training can provide positive learning experiences. The PjBL activities also helped the process of knowledge and skills construction in the form of technical skills. Aspects of teamwork, project management, and relevance can also build soft skills for trainees during the training.

Keywords: Project-Based Learning, Vocational Training, Soft Skills, Technical Skills.
\end{abstract}

\section{INTRODUCTION}

Vocational Education and Training (VET) is not only applied in formal education systems but also non-formal systems such as community-based adult learning centers, technical skills centers, and technical training centers [1], [2]. In Indonesia, one of the non-formal Vocational Education and Training institutions is organized by Balai Latihan Kerja as a Vocational Training Center that uses competency-based education and training. Vocational Training Center is a place that aims to train the community with technical and vocational skills and to increase labor productivity according to the needs of the labor market. It was designed for job seekers or employees who want to develop skills to work in particular fields. One of the training programs is a computer graphic design that aims to produce competent graphic designers.

Computer Graphic Design training will be effective if it has learning content that can accommodate all the skills needed to become a competent graphic designer in the workplace [3]. The basic principles and concepts of graphic design are given during training as a basis for applying them

Revised Manuscript Received on May 15, 2020.

* Correspondence Author

Muhammad Kholil*, Technology and Vocational Education Postgraduate Program, Universitas Negeri Yogyakarta, Yogyakarta, Indonesia. Email: muhammadkholil.2018@student.uny.ac.id

Sutarto Hadiprayitno, Department of Civil Engineering, Faculty of Engineering, Universitas Negeri Yogyakarta, Yogyakarta, Indonesia. Email: sutartohp19@gmail.com.

(C) The Authors. Published by Blue Eyes Intelligence Engineering and Sciences Publication (BEIESP). This is an open access article under the CC BY-NC-ND license (http://creativecommons.org/licenses/by-nc-nd/4.0/) to production and implementing a design brief. Learning content related to the operation of $2 \mathrm{D}$ design software such as Corel Draw and Adobe Photoshop is provided to execute tasks such as Vector-Drawing, Image-Editing, and Page-Layout. The complexity of computer graphics systems that can display colors, symbols, spatial organization, typography, and temporal sequences requires the use of sophisticated software [4]. The final work of production is presented to the client as a form of responsibility of a designer. All learning contents in computer graphic design training aim to develop technical skills and soft skills of trainees. The combination of knowledge and skills will produce technical skills that must be possessed by a computer graphic designer including conceptual design skills, content skills, technical design skills, and software skills. Work attitude such as collaborative and communicative to work on a project in the form of teamwork is also needed so that it can develop a process management skills of a designer [5], [6]. Those aspects are in line with the needs of the world of work which requires employability skills that consist of technical skills and soft skills. The industry also expects that the soft skills of employees are beneficial for supporting their career development and company sustainability [7], [8].

Practical challenges in competency-based training are authentic contextual learning activities related to real problems in the world of work that cannot be optimal. That risks reducing the role of trainees in the workplace. On the other hand, the VET system that focuses on competence must combine knowledge, work attitudes, and attain practical skills relevant to work and be supported by technology studies [9], [10]. Training institutions can use a competency-based approach as a starting point for learning. Then the next stage can be continued using alternative learning models containing authentic tasks to facilitate participant skills in all competency models in the learning experiences [11]. The effective learning process in VET is an important point in improving the competency of prospective workers. The selection of learning models must be appropriately adjusted to the characteristics of the competency training material, learners, and relevant work world problems [12], [13]. The Project-Based Learning (PjBL) model is an innovative approach in vocational learning that is suitable to provide learning experiences to produce a tool or product design. The PjBL model is authentic learning where real problems in the world of work are raised as the basis of problems that are solved using projects [14], [15]. Project-based learning is also effective in supporting the development of skills in the real world that are important such as complex problem solving, critical thinking, analyzing and evaluating information.
Blue Eyes Intelligence Engineering

\& Sciences Publication
(C) Copyright: All rights reserved.

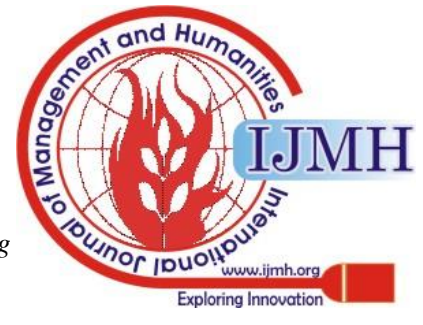


Project management in the learning process of PjBL can also develop various soft skills of learners such as collaboration, self-management skills, and effective communication related to work [16], [17], [18]. Implementation of $\mathrm{PjBL}$ in learning that utilizes computer technology can optimize the ability of learners to apply technical knowledge, to develop computer skills, and to acquire practical skills for the use of software where learners work in teams to work on projects [19], [20]. The PjBL model can encourage learners to carry out learning activities with high motivation because there are challenges, tasks or problems that they have to solve. All activities in PjBL make learners can improve their mastery of work competencies in efforts to solve problems with technology and manage work time. The purpose of this study is to investigate and describe the perceptions of trainees on Project-Based Learning that have been implemented in the Computer Graphic Design Training Program at the Vocational Training Center at Sleman Regency. The focus of this study is to know the benefits of Project Based Learning obtained by trainees based on aspects of technical skill development, teamwork, project management, and relevance.

\section{METHODS}

This research is quantitative research with a descriptive approach. Data collection techniques in this study used questionnaires. It uses a Likert scale with 4 scales from Strongly Disagree to Strongly Agree. The population was 31 participants in the computer graphic design training program at the Vocational Training Center in Sleman Regency. The questionnaire consisted of 4 constructs namely: technical skill development, project management, teamwork, and relevance which were compiled based on previous research and studies. The statement on the instrument was more focused on the trainees' perceptions of the PjBL experiences that were applied to computer graphic design training. The data analysis technique is done by collecting respondents' data, analyzing data, and describing the data collected. The average data of each statement item will be converted into percentage form and then categorized as in table 1 [21].

Percentage of Score $=\frac{\text { Score obtained }}{\text { Ideal Score }} \times 100 \%$

Table 1. Categorization of Trainees' Perception Scores

\begin{tabular}{|c|c|}
\hline Score Range (\%) & Category \\
\hline $81-100$ & Very High \\
\hline $61-80$ & High \\
\hline $41-60$ & Enough \\
\hline $21-40$ & Low \\
\hline $0-20$ & Very Low \\
\hline
\end{tabular}

\section{RESULT AND DISCUSSION}

Questionnaire data were analyzed by interpreting the percentage of answers given by trainees. Aspects assessed to reveal trainees' perceptions toward the benefits of the $\mathrm{PjBL}$ experiences are technical skill development, project management, teamwork, and relevance. Each of these aspects is then elaborated in several statement items addressed to the trainees. It is presented in table 2 below.
Table 2. Data of Questionnaire Result

\begin{tabular}{|c|c|c|c|}
\hline No & Aspect & Mean & Percentage \\
\hline a. & $\begin{array}{l}\text { Technical Skill } \\
\text { Development }\end{array}$ & 3,56 & $88.91 \%$ \\
\hline 1 & $\begin{array}{l}\text { Training with the PjBL } \\
\text { model increases knowledge } \\
\text { and skills using computer } \\
\text { graphic design software }\end{array}$ & 3,68 & $91.94 \%$ \\
\hline 2 & $\begin{array}{l}\text { Training with the PjBL } \\
\text { model deepens the basic } \\
\text { concepts and production } \\
\text { techniques in graphic design }\end{array}$ & 3,52 & $87.90 \%$ \\
\hline 3 & $\begin{array}{l}\text { This training made me able } \\
\text { to apply theoretical concepts } \\
\text { into practice in producing } \\
\text { product content. }\end{array}$ & 3,55 & $88.71 \%$ \\
\hline 4 & $\begin{array}{l}\text { This training made me able } \\
\text { to explain the results of my } \\
\text { design project to others. }\end{array}$ & 3,48 & $87.10 \%$ \\
\hline b. & Project Management & 3,46 & $86.49 \%$ \\
\hline 5 & $\begin{array}{l}\text { I was able to establish a } \\
\text { project design strategy } \\
\text { based on a case or consumer } \\
\text { demand through this } \\
\text { training }\end{array}$ & 3,48 & $87.10 \%$ \\
\hline 6 & $\begin{array}{l}\text { This training provides me to } \\
\text { find solutions for clients' } \\
\text { problems with coherent } \\
\text { logic. }\end{array}$ & 3,39 & $84.68 \%$ \\
\hline 7 & $\begin{array}{l}\text { I became able to manage the } \\
\text { implementation of the entire } \\
\text { design production process. }\end{array}$ & 3,39 & $84.68 \%$ \\
\hline 8 & $\begin{array}{l}\text { This training makes me } \\
\text { responsible for the results of } \\
\text { the projects that I make. }\end{array}$ & 3,58 & $89.52 \%$ \\
\hline c. & Teamwork & 3,48 & $87.10 \%$ \\
\hline 9 & $\begin{array}{l}\text { I feel more open to accept } \\
\text { criticism or suggestions } \\
\text { from friends in a graphic } \\
\text { design project. }\end{array}$ & 3,35 & $83.87 \%$ \\
\hline 10 & $\begin{array}{l}\text { This training creates good } \\
\text { communication and } \\
\text { discussion between friends } \\
\text { in planning design projects. }\end{array}$ & 3,58 & $89.52 \%$ \\
\hline 11 & $\begin{array}{l}\text { This training creates } \\
\text { collaborative work } \\
\text { assignments between friends } \\
\text { well in graphic design } \\
\text { projects. }\end{array}$ & 3,52 & $87.90 \%$ \\
\hline d. & Relevance & 3,35 & $83.87 \%$ \\
\hline 12 & $\begin{array}{l}\text { The design project that I } \\
\text { created is based on a real } \\
\text { case or customer request. }\end{array}$ & 3,58 & $89.52 \%$ \\
\hline 13 & $\begin{array}{l}\text { The design results are } \\
\text { manifested in real products } \\
\text { suitable in the field } \\
\text { (example: pamphlets, } \\
\text { brochures, posters, etc). }\end{array}$ & 3,16 & $79.03 \%$ \\
\hline 14 & $\begin{array}{l}\text { The existing problems can } \\
\text { trigger my creativity in } \\
\text { making product designs. }\end{array}$ & 3,32 & $83.06 \%$ \\
\hline
\end{tabular}

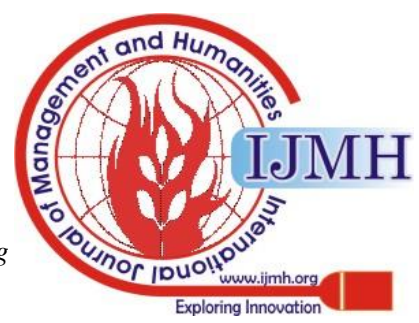


Based on table 2, the aspect of Development Technical Skill shows that the largest point is trainees feel the greatest benefit in terms of increasing their ability to operate computer graphic design software. In the Project Management aspect, it can be said that the benefits of the PjBL experience train a sense of responsibility for trainees and develop the ability to set project strategies. In the Teamwork aspect, it also shows that the benefits of the PjBL experience can train communication and collaboration skills in a team or workgroup. In the aspect of Relevance, it can be said that PjBL provides experiences that describe activities such as the real world of work, and the creativity of trainees can be stimulated through problems.

In general, the results of the analysis of the calculation of statistical data in table 2 show that the trainee's response was reviewed from four aspects, namely Technical Skill Development of 88.91\%; Project Management of $86.49 \%$; Teamwork of $87.10 \%$; and Relevance of $83.87 \%$. Based on table 1 , all of the data are in the very high category, so it can be concluded that trainees gave positive responses to $\mathrm{PjBL}$ activities in general. Those activities provide good experiences for trainees to develop Technical Skills such as using computer graphic design software, and understanding concepts and techniques in graphic design. It also trains trainees to prepare projects related to real-world problems and integrates technology to maximize learning [22]. In the aspects of Project management, Teamwork, and Relevance also provide important experiences for the development of soft skills of trainees, among others: responsibility, communication, collaboration, problem-solving, etc. Previous studies also found that students' responses to PjBL activities [23] from the aspect of teamwork and project management gave a positive impact on the development of soft skills of each individual. They also felt that the project at PjBL could improve the technology skills to use specific software effectively [19]. So it can be said that the PjBL activity can provide suitable learning situations in the development of technical skills and soft skills of trainees.

\section{CONCLUSION}

This study revealed that the experiences from the PjBL activities provided benefits for trainees in the Computer Graphic Design Training. The implementation of the PjBL model in the training program has the potential to create an authentic and memorable learning experience for trainees. In the end, the findings of this study show that PjBL provides a positive experience for trainees, especially in the process of knowledge and skills construction in the form of technical skills. It can also help build soft skills in aspects of teamwork, project management, and relevance. Learning situations that are formed from these aspects can support the process in which trainees build an accumulation of knowledge and practical skills [24]. The benefits gained from the $\mathrm{PjBL}$ experiences make it is suitable to be implemented as an alternative vocational learning model in graphic design training. It must also pay attention to the material characteristics and competencies that must be achieved by trainees.

\section{REFERENCES}

1. T. Agrawal, "Vocational education and training programs ( VET ): An Asian perspective," Asia-Pacific J. Coop. Educ., vol. 14, no. 1, pp. 15-26, 2013.

2. M. Singh, Global Perspectives on Recognising Non-formal and Informal Learning. Hamburg: Springer, 2015.

3. N. E. Ibezim and E. C. Ireh, "Computer Graphics Skills Required for Effective Entrepreneurial Development," Rev. Eur. Stud., vol. 9, no. 2, pp. 45-52, 2017, doi: 10.5539/res.v9n2p45.

4. A. Marcus, "Graphic Design for Computer Graphics," Comput. Ind., vol. 5, no. 1, pp. 51-63, 1984.

5. P. R. N. Dziobczenski and O. Person, "Graphic Designer Wanted : A Document Analysis of the Described Skill Set of Graphic Designers in Job Advertisements from the United Kingdom,” Int. J. Des., vol. 11, no. 2, pp. 41-55, 2017.

6. P. R. N. Dziobczenski, O. Person, L. M. Tonetto, and R. R. Mandelli, "Requests from Companies and Requirements for Design Education in Brazil: where do they meet ?," in Proceedings of DRS 2018 Catalyst, 2018, pp. 2823-2835, doi: 10.21606/dma.2018.535.

7. O. K. Bee and T. S. Hie, "Employers' Emphasis on Technical Skills and Soft Skills in Job Advertisements," English Teach., vol. XLIV, no. 1, pp. 1-12, 2015.

8. R. Harris and B. Clayton, "Editorial: the importance of skills - but which skills ?,” Int. J. Train. Res., vol. 16, no. 3, pp. 195-199, 2019, doi: 10.1080/14480220.2018.1576330.

9. A. Brightwell and J. Grant, "Competency-based training who benefits,” Postgrad. Med. J., vol. 89, no. 1048, pp. 107-110, 2012, doi: doi: 10.1136/postgradmedj-2012-130881.

10. N. Alam, "The Role of Technical Vocational Education And Training in Human Development : Pakistan as a Reference Point," Eur. Sci. J. vol. 11, no. 10, pp. 35-50, 2015.

11. R. Ford and R. Meyer, "Competency-based Education 101," Procedia Manuf., vol. 3, pp. 1473-1480, 2015, doi 10.1016/j.promfg.2015.07.325.

12. F. A. Haolader, M. R. Ali, and K. M. Foysol, "The taxonomy for learning, teaching and assessing: Current practices at polytechnics in Bangladesh and its effects in developing students' competences," Int J. Res. Vocat. Educ. Train., vol. 2, no. 2, pp. 99-118, 2015, doi: 10.13152/IJRVET.2.2.9.

13. R. Wallace, "Social Partnerships in Learning: Connecting to the Learner Identities of Disenfranchised Regional Learners," in Vocational Learning: Innovative Theory and Practice, R. Catts, I. Falk, and R. Wallace, Eds. Springer Netherlands, 2011, pp. 11-31.

14. N. V. Vargas, J. L. A. Ortiz, and V. M. A. Ceballo, "Project Based Learning in the Technical and Vocational Education and Training,' Int. J. Environ. Sci. Educ., vol. 13, no. 9, pp. 767-776, 2018.

15. D. Laur, Authentic Learning Experiences : A Real-World Approach to Project-Based Learning. New York: Routledge, 2013.

16. J. L. Hart, "Interdisciplinary project-based learning as a means of developing employability skills in undergraduate science degree programs," J. Teach. Learn. Grad. Employab., vol. 10, no. 2, p. 50, 2019, doi: 10.21153/jtlge2019vol10no2art827.

17. S. Bell, "Project-Based Learning for the 21st Century: Skills for the Future," Clear. House A J. Educ. Strateg. Issues Ideas, vol. 83, no. 2 , pp. 39-43, 2010, doi: 10.1080/00098650903505415

18. E. de S. Zancul, T. T. Sousa-Zomer, and P. A. Cauchick-Miguel, "Project-based learning approach: Improvements of an undergraduate course in new product development," Production, vol. 27, no. spesial, pp. 1-14, 2017, doi: 10.1590/0103-6513.225216.

19. A. Asan and Z. Haliloglu, "Implementing Project Based Learning in Computer Classroom.," Turkish Online J. Educ. Technol. - TOJET, vol. 4, no. 3, pp. 68-81, 2005.

20. R. Pucher and M. Lehner, "Project Based Learning in Computer Science - A review of more than 500 projects," Procedia - Soc. Behav. Sci., vol. 29, pp. 1561-1566, 2011, doi: 10.1016/j.sbspro.2011.11.398.

21. E. D. T Puspitasari and Soeharto, "Perception of vocational education students on the utilization of blended learning models" J. Phys.: Conf. Ser.1273 012046, 2019, doi: 10.1088/1742-6596/1273/1/012046

22. N. F. Jumaat, Z. Tasir, N. D. A. Halim, and Z. M. Ashari, "Project-based learning from constructivism point of view," Adv. Sci. Lett., vol. 23, no. 8, pp. 7904-7906, 2017, doi: 10.1166/asl.2017.9605.

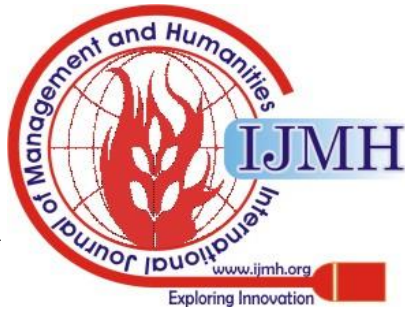


23. F. Musa, N. Mufti, R. A. Latiff, and M. M. Amin, "Project-based learning ( PjBL ): inculcating soft skills in 21st century workplace," Procedia - Soc. Behav. Sci., vol. 59, no. 2006, pp. 565-573, 2012, doi: 10.1016/j.sbspro.2012.09.315

24. M. Abdulwahed, Z. K. Nagy, and R. Blanchard, "Constructivist project based learning design, a cybernetics approach," in IMSCI 2008 - 2nd International Multi-Conference on Society, Cybernetics and Informatics, Proceedings, 2008, vol. 2, pp. 119-126.

\section{AUTHORS PROFILE}

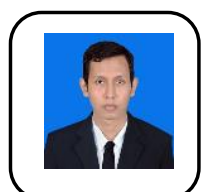

Muhammad Kholil, is currently a student of Technology and Vocational Education, Postgraduate Program at Universitas Negeri Yogyakarta, Indonesia. He has a driven passion towards the use of learning methods in the field of Vocational Education, and Training. the research he had done was themed on the development of an audio video engineering module for grade 2 in vocational high school.

Sutarto Hadiprayitno, is a lecturer at the College of Engineering and the Graduate School of the Universitas Negeri Yogyakarta, Indonesia. He teaches civil engineering in, undergraduate, and vocational curriculum development in postgraduate. His research areas include vocational education curriculum, vocational education management and training.

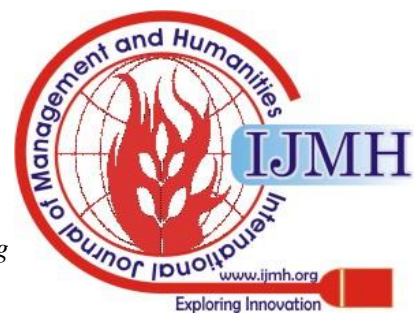

